\title{
Monitoring Aclonifen Remediation in Soil with a Laboratory-Scale Research
}

\author{
G. Onder Erguven, ${ }^{1}$ Hurrem Bayhan, ${ }^{2}$ Goksel Demir, ${ }^{3}$ Bahar Ikizoglu, ${ }^{2}$ and Gurdal Kanat ${ }^{2}$ \\ ${ }^{1}$ Environmental Engineering Department, Tunceli University, 62000 Tunceli, Turkey \\ ${ }^{2}$ Environmental Engineering Department, Faculty of Civil Engineering, Yildiz Technical University, Esenler, \\ 34220 Istanbul, Turkey \\ ${ }^{3}$ Department of Urban and Regional Planning, Kırklareli University, 39000 Kırklareli, Turkey
}

Correspondence should be addressed to G. Onder Erguven; gokhanondererguven@gmail.com

Received 28 November 2015; Revised 14 January 2016; Accepted 27 January 2016

Academic Editor: Mohamed R. Berber

Copyright (C) 2016 G. Onder Erguven et al. This is an open access article distributed under the Creative Commons Attribution License, which permits unrestricted use, distribution, and reproduction in any medium, provided the original work is properly cited.

\begin{abstract}
Aclonifen was used as the most preferable type of herbicide which is used in sunflower farming in the Thrace Region. Bacteria and fungi were isolated from the soil samples taken from the Thrace Region, and a mixed culture was prepared from equal volumes $\left(10^{8} \mathrm{CFU} / \mathrm{mL}\right)$ of liquid cultures of microorganisms. Including the witness sample, five different setups were prepared, to which Aclonifen, with a concentration of $1900 \mu \mathrm{g} / \mathrm{L}$, was added. Each unit was diluted with distilled water for six weeks. The water filtered at this stage was measured for chemical oxygen demand (COD), biochemical oxygen demand, total organic carbon (TOC), and Aclonifen. Additionally, $\mathrm{pH}$ and dissolved oxygen measurement was performed. According to the results of the study, the highest bioremediation was observed in the soil sample to which $10 \mathrm{~mL}$ of mixed culture of microorganisms was added and Aclonifen, $\mathrm{COD}, \mathrm{BOD}_{5}$, and TOC remediation was observed as $93.2 \%, 97.8 \%, 98.8 \%$, and $98.7 \%$, respectively.
\end{abstract}

\section{Introduction}

Soil is exposed to certain micropollutants due to pesticide use to control pests and increase crop yields. If the necessary measures are not taken, the said pollutants are partly subject to natural bioaccumulation as a result of biodegradation. Micropollutants that pass along the food chain may lead to health problems even in humans. Furthermore, they not only pollute underground water through rain but also pollute water resources in the receiving environment through surface water flows.

In order to avoid such situations, the problems that are caused by residues in areas where pesticides were used should be solved. In biological processes, various microorganisms in soil consume pesticide residues as nutrients. This is a significant mechanism for the remediation of pesticides in soil.

Biodegradation is necessary for remediation of pesticide residues in soil and in underground waters. The microorganisms that are required for such process are present in the soil
[1]. A study on the remediation of the active substance Ethior in anaerobic conditions by mesophilic bacteria isolated from soil polluted by pesticides suggests that the bacteria Pseudomonas and Azospirillum achieve effective remediation [2]. Similarly, another study suggested that the enzyme of Penicillium chrysosporium, which is a type of fungus, is able to metabolize micropollutants such as pesticides and remediate the toxic effects of chemicals included in pesticides by degrading lignin up to $76 \%$ within 15 days and $94 \%$ within 30 days [3]. The literature suggests that, in studies carried out in aerobic and anaerobic facilities where mixed bacterial cultures are used, endosulfan is biologically degraded up to 96\% [4].

Microbial degradation is not only a significant mechanism in pesticide control in soil but also an environmental approach from an agricultural perspective. Temperature and humidity are two fundamental environmental parameters that control the microbial degradation of pesticides in soil. Pesticide degradation is generally slower in dry soil than in humid soil [5]. 
According to Khoury et al. [6], since soil is a complex system, degradation of herbicides is affected by many factors such as temperature, $\mathrm{pH}$, humidity, differences in plowing methods, and type of crop. According to many researchers, while the $\mathrm{pH}$ of the soil, speed and time of pesticide application, and content of organic substances are the main parameters in laboratory-scale studies, the humidity and temperature of the soil are the main factors that affect pesticide degradation on the field [7].

This study identified the types of bacteria and fungi in soil samples taken from the Thrace Region in Turkey and examined the bioremediation of Aclonifen, which is a herbicide most preferred by farmers in sunflower farming, based on the concentration of Aclonifen utilized.

Aclonifen is generally used for sunflowers [8, 9]. It is an herbicide with a diphenyl ether nucleus which has been authorized for agronomic use in Europe in 1983 and in Turkey since 1994, used as $1.8 \mathrm{~kg} /$ ha for sunflowers [10, 11]. Probably for that reason (it is a common herbicide for sunflowers), only a few researches can be found in the articles of northern developed countries and in the literature. Also it can be seen in the literature that a few studies have explored the combination of fungi and bacteria to remove pesticide from the aqueous phase [12]. For that reason, our study has an importance to complete the information in the literature.

\section{Materials and Methods}

2.1. Isolation and Molecular Characterization of Fungi and Bacteria. For the isolation of fungi and bacteria, the soil samples taken from the Thrace Region, from depths of 0$20 \mathrm{~cm}$, were first placed in sterile glass containers [28]. Soil samples were analyzed before herbicide application and there were no background of Aclonifen or other diphenyl ether herbicides in the studied field. The physical and chemical characteristics of these soil samples are presented in Table 1. Approximately $10 \mathrm{~g}$ of soil was diluted up to $10^{-4}$ in isotonic water containing $0.8 \%$ sodium chloride. $0.1 \mathrm{~mL}$ of diluent was planted in aseptic conditions in plate count agar (PDA), dextrose casein peptone agar, potato dextrose agar, dichloran rose bengal chlorinated agar, malt extract agar, Sabouraud dextrose agar, and yeast extract agar feedlots that were previously sterilized and poured on plates [29]. Rose bengal was used for the selective isolation and enumeration of fungi species. Following the inoculation, the petri dishes ( 3 replicates for each) were placed in incubators at $20^{\circ} \mathrm{C}$ for three days (bacteria) and for five days (fungi). Five species of bacteria and six species of fungi colonies that were grown in petri dishes were separated by their morphology and placed in enrichment feedlots and incubated at $20^{\circ} \mathrm{C}$ and $150 \mathrm{rpm}$. [30].

The fungi produced for molecular studies were placed in malt extract agar, whereas the bacteria were placed in standard plate count agar inclined feedlots. The genetic analysis system (Beckman Coulter CEQ 8000) and MyCycler thermal cycler system, electrophoresis device, and gel documentation system (ORTE) were used for PCR procedures. Characterization studies were carried out in line with the guidelines of the Wizard Genomic DNA Purification Kit. Methods of "Isolating Genomic DNA from Gram Positive and Gram Negative Bacteria" were used for bacteria and methods of "Isolating Genomic DNA from Yeast" [31] were used for fungi. First, nucleic acid extraction was done in the samples. The DNA obtained were stored at $-20^{\circ} \mathrm{C}$. The PCR method was employed and thermal cyclers were used to reproduce $16 \mathrm{~S}$ rRNA genes of these DNA mixtures, which were followed by identification of methanogenic species and analysis of DNA and DGGE sequences.

2.2. Characterization of Bacteria. Streak plate plantation was employed to homogenize the colonies marked in petri dishes and to turn them into a single colony. Phire Hot Start II DNA Polymerase was utilized to obtain bacterial 16S ribosomal general primers and PCR bands of various lengths (1000$3000 \mathrm{bp})$.

\subsubsection{Cycle and Pipetting Conditions}

Thermal Cycle Conditions. They are as follows: Thermal Cycle Conditions: 1 cycle: $98^{\circ} \mathrm{C}-5 \mathrm{~min}, 40$ cycle: $98^{\circ} \mathrm{C}-5 \mathrm{~s}, 72^{\circ} \mathrm{C}-20 \mathrm{~s}$, 1 cycle $72^{\circ} \mathrm{C}-4 \mathrm{~min}, 4^{\circ} \mathrm{C}-\infty$.

Identification of bacteria isolated and coded between B1 and B5 was carried out in line with 16S RNA Universal Primers 27F ( $5^{\prime}$-AGAGTTTGATCCTGGCTCAG-3'; Escherichia coli positions 8-27), 16S rRNA universal primers 27F (5' AGAGTTTGATCCTGGCTCAG-3' ${ }^{\prime}$; Escherichia coli positions 8-27), and 1492R (5' TACGGYTACCTTGTTACGACTT $3^{\prime}$ positions 1492-1512) (Weisburg et al. [32]).

Final Concentrations. They are as follows: total reaction volume $20 \mu \mathrm{L}$; $1 \mathrm{X}$ Phire animal tissue PCR tampon (contains dNTPs and $\mathrm{MgCl}_{2}$ ) $/ 0.5 \mu \mathrm{m}$ forward primer, $0.5 \mu \mathrm{m}$ adverse primer, Phire Hot Start II DNA polymerase and $\mathrm{H}_{2} \mathrm{O}$ were used.

2.3. Characterization of Fungi. The fungi were first planted in petri dishes (streak plate) containing PDA to ensure reproduction from a single spore. They were grown at room temperature and the fungus colonies that developed from a single point were transferred to another petri dish with PDA. They were grown until they reached a volume sufficient for DNA isolation. The fungi were scratched with a sterile bistoury and crushed with liquid nitrogen in a sterile muddler. Then, DNA isolation was performed on the pulverized hyphae in line with the Promega WizardÝ Genomic DNA Purification Kit method (3.E. Isolating Genomic DNA from Plant Tissue).

The DNAs were subjected to the PCR method with an ordinary Taq polymerase by using several combinations of primers of the ITS (Internal Transcribed Spacer) region, which is generally used for fungus identification. The PCR conditions are as follows.

Thermal Cycle Conditions. They are as follows: Thermal Cycle Conditions: 1 cycle: $94^{\circ} \mathrm{C}-3 \mathrm{~min}, 35$ cycle: $94^{\circ} \mathrm{C}-15 \mathrm{~s}, 55^{\circ} \mathrm{C}-30 \mathrm{~s}$, $72^{\circ} \mathrm{C}-30 \mathrm{~s}, 1$ cycle: $72^{\circ} \mathrm{C}-5 \mathrm{~min}$. 
TABLE 1: Physical and chemical characteristics of the soil sample.

\begin{tabular}{|c|c|c|c|c|}
\hline Characteristics of the Soil & Unit & Methods & Result of the analysis & $\begin{array}{l}\text { Evaluation of soil characteristics } \\
\text { for sunflower growing }\end{array}$ \\
\hline $\mathrm{pH}$ & & Richards [13] & 7.6 & Mild alkali \\
\hline Lime & \multirow{9}{*}{$\%$} & Tüzüner [14] & 16.6 & Low \\
\hline Salt & & Richards [13] & 0.05 & Unsalted \\
\hline Saturation & & Tüzüner [14] & 64 & Clayed loamy \\
\hline Organic substance & & Walkley and Black [15] & 2.1 & Moderate \\
\hline Total nitrogen (Kjeldahl) & & Bremner $[16]$ & 0.1 & Moderate \\
\hline Cation exchange capacity (CEC) & & Sodium acetate, Tüzüner [14] & 31.50 & Sufficient \\
\hline Silt & & & 5 & Low \\
\hline Sand & & Bouyoucos [17] & 32 & Sufficient \\
\hline Humidity & & & 21 & Sufficient \\
\hline Extractable P & \multirow{2}{*}{$\mathrm{Kg} \mathrm{K}_{2} \mathrm{O} / \mathrm{da}$} & Kacar and Kovanc1 [18] & 43.70 & High \\
\hline Extractable K & & Kacar [19] & 49.10 & Sufficient \\
\hline Extractable Fe & \multirow{4}{*}{ ppm } & \multirow{4}{*}{ DTPA-ICP } & 2.97 & \multirow{4}{*}{ Sufficient } \\
\hline Extractable Mn & & & 1.67 & \\
\hline Extractable Zn & & & 0.79 & \\
\hline Extractable $\mathrm{Cu}$ & & & 0.65 & \\
\hline
\end{tabular}

Final Concentrations. They are as follows: total reaction volume $25 \mu \mathrm{L}$ : $1 \mathrm{x}$ Taq polymerase buffer, $1.5 \mathrm{mM} \mathrm{MgCl}_{2}, 0.4 \mu \mathrm{M}$ forward primer, $0.4 \mu \mathrm{M}$ reverse primer, $0.5 \mathrm{mM} \mathrm{dNTP}, 1 \mathrm{U}$ Taq polymerase and $200 \mathrm{ng}$ DNA.

At the end of the PCR procedure, only the M1 (Penicillium trichoderma), M4 (Metacordyceps chlamydosporia), and M6 (Alternaria alternata) fungi yielded bands of expected lengths. A better polymerase, the One-Taq polymerase, was used in other fungi.

A reaction of $25 \mu \mathrm{L}$ was produced in One-Taq polymerase conditions. Tm was used between 53 and $57^{\circ} \mathrm{C}$ (various Tm's were attempted for each combination according to the sintering point of primers). Three primers were designed and two yielded positive results. After these bands were cut from the agarose gel and cleaned, the PCR reaction was directly sent for sequence analysis. If the sequence reaction on the bands cut out of the agarose gel did not yield positive results, reamplification was performed with One-Taq polymerase. The bands cut out of the agarose gel were cleaned with the Thermo Scientific Gene JET gel extraction kit.

2.4. Preparation of the Soil Test Units. Holes with a diameter of $0.2 \mathrm{~cm}$ were drilled in the bottom of five clean plastic bottles with a diameter of $10 \mathrm{~cm}$. These bottom parts were then cut out and placed inside the bottles near their openings so that they functioned as filters. $7 \mathrm{~cm}$ of agricultural soil (approximately 350 grams), which was sterilized at $105^{\circ} \mathrm{C}$ for four days, was placed in each setup (the soil had not been exposed to herbicides) (Figure 1).

The surface area of five soil units was $7.85 \times 10^{-3} \mathrm{~m}^{2}$. One thousand nine hundred $\mu \mathrm{g} / \mathrm{L}$ of Aclonifen was added to each setup (two times of the dose suggested for agricultural land). The soil in each unit was grafted with culture solutions of $100 \mathrm{~mL}$, to which $1 \mathrm{~mL}, 2 \mathrm{~mL}, 5 \mathrm{~mL}$, and $10 \mathrm{~mL}$ of cells suspension containing viable cells (approximately $10^{9} \mathrm{CFU} / \mathrm{mL}$ for

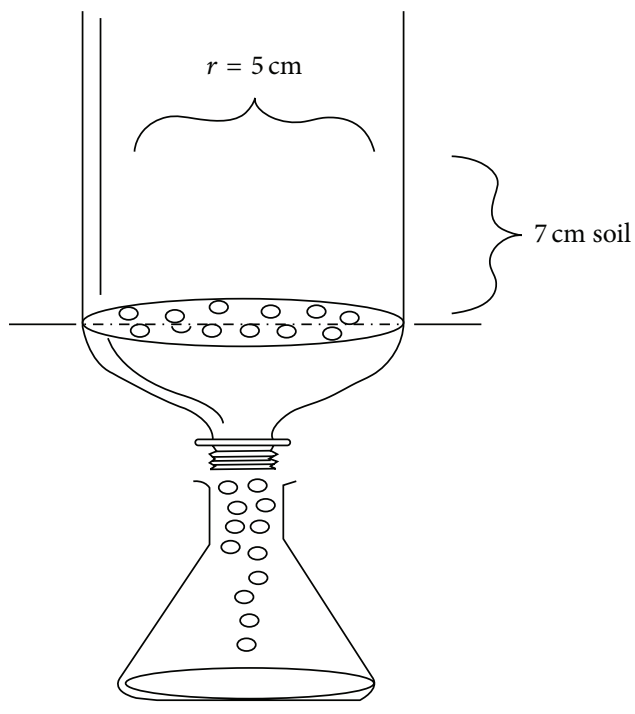

FIgURE 1: The soil unit.

each 5 different species of bacteria and 6 different species of fungi) were added with a sterile pipette. The microorganisms were reproduced in enriched feedlots and incubated for a week and had started to seek nutrients after consuming the existing substrate. The soil in the witness unit was not grafted with any microorganisms. For control group, one unit with sterile soil (without microorganism) and $1900 \mu \mathrm{g} / \mathrm{L}$ Aclonifen is used for determination of decreasing of COD, $\mathrm{BOD}_{5}, \mathrm{TOC}$, Aclonifen, $\mathrm{pH}$, and D.O parameters.

2.5. Preparation of the Herbicide Solution. Aclonifen was purchased from the BAYER Company under the commercial name, Chekic 600. The herbicide solution was prepared by 
adding $400 \mathrm{~mL}$ of Chekic (240 $\mathrm{g}$ of Aclonifen) to 10 liters of tap water.

2.6. Remediation of Aclonifen in Soil. Each week, $200 \mathrm{~mL}$ of distilled water was added to each unit and the filtrates were collected in the clean bottles below. The filtrates were first filtered through a rough paper filter and then through membrane filters of $0.45 \mu \mathrm{m}$ to identify the COD, $\mathrm{BOD}_{5}, \mathrm{TOC}$, Aclonifen, $\mathrm{pH}$, and dissolved oxygen values. All experiments were performed in triplicate. The COD test was performed in line with the closed reflux titrimetric method identified in the Standard Method 5220C. The TOC test was performed in line with the method of burning at a high temperature identified in the Standard Method 5310A, and the $\mathrm{BOD}_{5}$ test was performed in line with the Standard Method 5210B (5-day BOD test). Aclonifen was identified with a liquid chromatographytandem mass spectrometry ( LC/MS/MS) Dionex Ultimate 3000 model device, with dimensions of $100 \mathrm{~mm} \times 2.1 \mathrm{~mm}$., $2.6 \mu$ and C18 Thermo Accucore columns in line with the Brominated Diphenyl Ethers in Water Soil, Sediment and Tissue by HRGC/HRMS, EPA 1614 Method. The furnace temperature of the column was $400^{\circ} \mathrm{C}$ and the autosampler temperature was $50^{\circ} \mathrm{C}$. The retention time was $9.0 \mathrm{~min}$., mass (Thermo Access Max) HESI ion source was 3500 volts, and the ion transfer tube temperature was $270^{\circ} \mathrm{C}$. Although the Sheath and Aux gases were $50 \mathrm{Arb}$ and $15 \mathrm{Arb}$, respectively, the amount limit was $15 \mathrm{ppb}$. The collision gas pressure was $1.5 \mathrm{~m}$ Torr. The LOD and LOQ values were $4 \mathrm{ppt}$ and $15 \mathrm{ppb}$. The ion transfers were 265.1 for the primary ion, 182.1 for the secondary ion, and 247.9 for the tertiary ion. The amount limit (method marker) was $0.1-1 \mathrm{mg} \mathrm{kg}^{-1}$. The average accuracy value was $\left(R^{2}\right) 0.999$ in the calibration curve.

All of the samples were spiked with surrogate and internal standards in order to maintain the sensitivity. Tetrachloro-mxylene (TMCX) was used as the surrogate standard. Quintozene was used as the internal standard. Before extraction, the surrogate standard was added to the samples.

Chromatograph vials were spiked before they were capped. The average recovery sensitivity was $86 \%$. For each species, the limit of detection (LOD) was calculated by the addition of the average witness value 3 three times of the standard deviation value. Values below the LOD value were not considered in the calculation. Witness samples were verified in each set of analysis, and all results were subject to witness verification. A manual measurement device, WTW multi $350 \mathrm{i}$, was used to identify the parameters, $\mathrm{pH}$ and dissolved oxygen. Measurements were done at room temperature. These tests were carried out once a week.

\section{Results and Discussion}

3.1. Results of the Identification of Bacteria and Fungi Species in Agricultural Soil. The types of the bacteria and fungi isolated and identified in the agricultural soil are given in Tables 2 and 3 , respectively.

3.2. Test Results of the Soil Units. TOC, COD, BOD, and Aclonifen remediation results and the graphs of dissolved

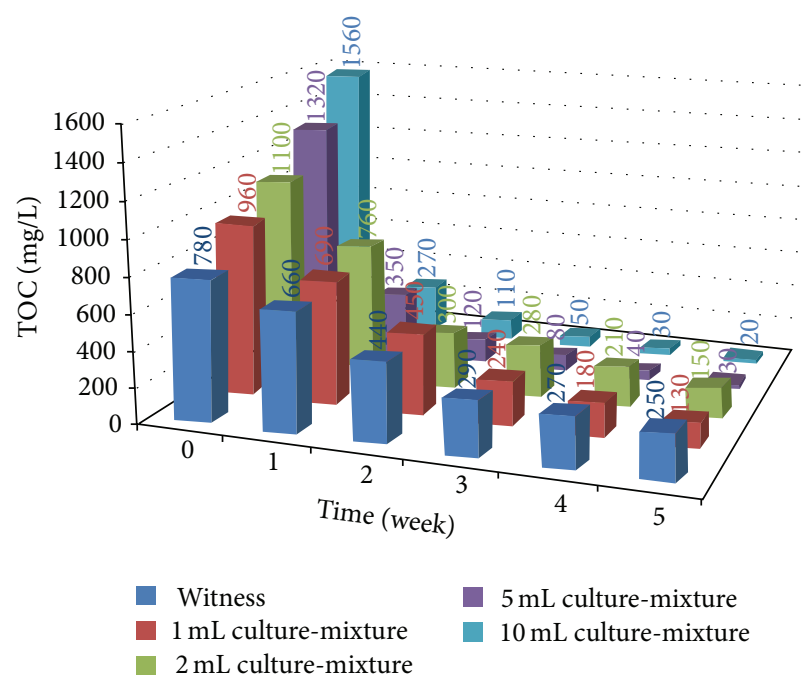

FIGURE 2: Total organic carbon results in the filtrate.

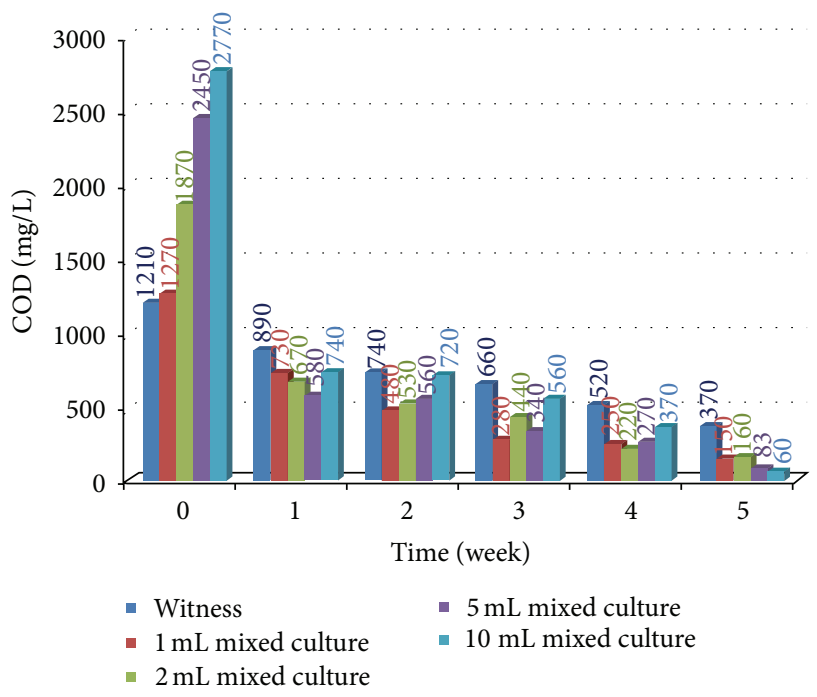

FIgURE 3: Chemical oxygen demand results in the filtrate.

oxygen and $\mathrm{pH}$ test results are given in Figures 2, 3, 4, 5, 6, and 7 , respectively.

When there is no Aclonifen in the environment, there are COD and TOC values arising from the system. Since the filtrate obtained from the soil displays the same values of $40 \mathrm{mg} / \mathrm{L}$ COD $30 \mathrm{mg} / \mathrm{L}$ TOC each week, no difference is observed in remediation performance when these values are subtracted from the COD and TOC values in presence of Aclonifen.

Figures 2, 3, and 4 show TOC, COD, and BOD results. Accordingly, the best remediation performance was $98.7 \%$ for TOC and $97.8 \%$ for COD in $10 \mathrm{~mL}$ mixed cultures. In COD tests, remediation performance in $5 \mathrm{~mL}$ mixed cultures was also similar to $96.6 \%$. At the end of the fifth week, TOC remediation was $67.9 \%$ and COD remediation was $69.4 \%$ in the witness environment. As Figure 4 shows, BOD remediation was $97.8 \%$ in $10 \mathrm{~mL}$ mixed culture for the same 
TABLE 2: Types of the bacteria identified.

\begin{tabular}{lccc}
\hline Accession number & Bacterial code and approximate species identity & Identity & Reference \\
\hline KF831394.1 & Bacillus simplex & $99 \%$ & {$[20]$} \\
HE646789.1 & Bacillus muralis & $99 \%$ & {$[21]$} \\
KF555623.1 & Micrococcus luteus & $99 \%$ & {$[22]$} \\
KC634108.1 & Micrococcus yunnanensis & $99 \%$ & {$[23]$} \\
HG530135.1 & Clostridium tetani & $99 \%$ & {$[24]$} \\
\hline
\end{tabular}

TABLE 3: First and second primers, sequences, and references of the identified fungi.

\begin{tabular}{|c|c|c|}
\hline $\begin{array}{l}\text { Fungi code and } \\
\text { approximate species } \\
\text { identity }\end{array}$ & $\begin{array}{c}\text { First primer } 5^{\prime}-3^{\prime} \text { sequence and } \\
\text { reference }\end{array}$ & $\begin{array}{c}\text { Second primer } 5^{\prime}-3^{\prime} \text { sequence and } \\
\text { reference }\end{array}$ \\
\hline Penicillium, Trichoderma & $\begin{array}{c}\text { ITS }^{*} \\
\text { GCATCGATGAAGAACGCAGC } \\
{[25]} \\
\end{array}$ & $\begin{array}{c}\text { ITS } \\
\text { ATCCCTACCTGATCCGAGGTC } \\
{[26]} \\
\end{array}$ \\
\hline $\begin{array}{l}\text { Penicillium } \\
\text { simplicissimum }\end{array}$ & $\begin{array}{c}\text { ITS } \\
\text { GAAGGTGAAGTCGTAACAAGG } \\
{[27]}\end{array}$ & $\begin{array}{c}\text { ITS } \\
\text { ATCCCTACCTGATCCGAGGTC } \\
{[26]}\end{array}$ \\
\hline Penicillium, Talaromyces & $\begin{array}{c}\text { ITS } \\
\text { TCCTCCGCTTATTGATATGC } \\
{[25]}\end{array}$ & $\begin{array}{c}\text { ITS } \\
\text { GAAGGTGAAGTCGTAACAAGG } \\
{[27]}\end{array}$ \\
\hline $\begin{array}{l}\text { Metacordyceps } \\
\text { chlamydosporia }\end{array}$ & $\begin{array}{c}\text { ITS } \\
\text { GAGACCGCCACTGTATTTCG } \\
{[26]} \\
\end{array}$ & $\begin{array}{c}\text { ITS } \\
\text { GCATCGATGAAGAACGCAGC } \\
{[25]} \\
\end{array}$ \\
\hline Stachybotrys chartarum & $\begin{array}{c}\text { ITS } \\
\text { TCCGTAGGTGAACCTGCGG } \\
{[25]}\end{array}$ & $\begin{array}{c}\text { ITS } \\
\text { ATCCCTACCTGATCCGAGGTC } \\
{[26]}\end{array}$ \\
\hline Alternaria alternata & $\begin{array}{c}\text { ITS } \\
\text { GCATCGATGAAGAACGCAGC } \\
{[25]}\end{array}$ & $\begin{array}{c}\text { ITS } \\
\text { ATCCCTACCTGATCCGAGGTC } \\
{[26]}\end{array}$ \\
\hline
\end{tabular}

${ }^{*}$ Internal Transcribed Spacer.

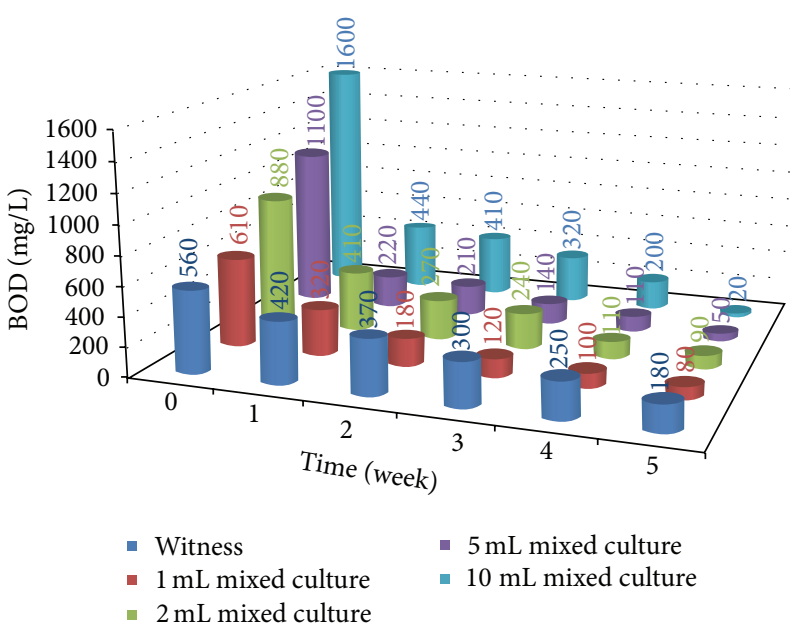

FIGURE 4: Biochemical oxygen demand results in the filtrate.

time period. The BOD remediation in the witness soil sample was $67.8 \%$. Since the Aclonifen concentration was the same in all environments, different results for TOC, COD, and BOD tests suggest that there was a change in the cultural environment. Since the nutrients in the witness culture

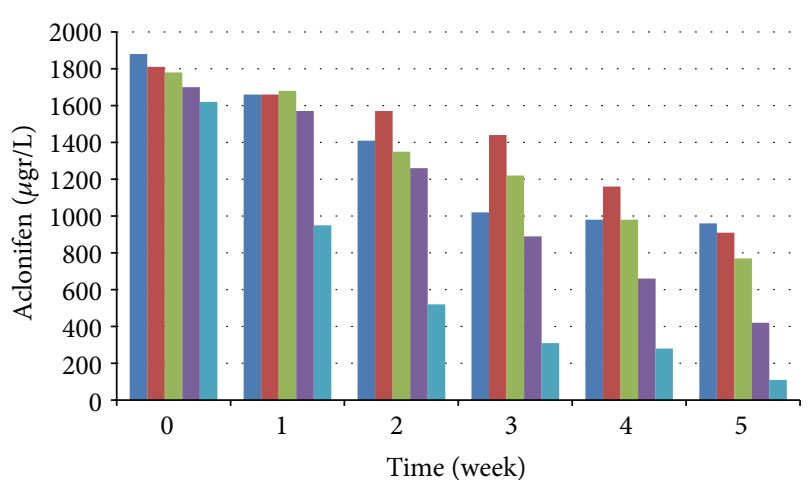

- Witness (with aclonifen) - $5 \mathrm{~mL}$ mixed culture filtrate

- $1 \mathrm{~mL}$ mixed culture filtrate $\quad-10 \mathrm{~mL}$ mixed culture filtrate

- $2 \mathrm{~mL}$ mixed culture filtrate

FIgURE 5: Aclonifen remediation results in the filtrate.

(without culture) and the $1 \mathrm{~mL}, 2 \mathrm{~mL}, 5 \mathrm{~mL}$, and $10 \mathrm{~mL}$ mixed cultures increased proportionally, the TOC, COD, and BOD values also increased.

As far as the cultural concentrations grafted in the soil increased, the TOC, COD, BOD, and Aclonifen remediation 


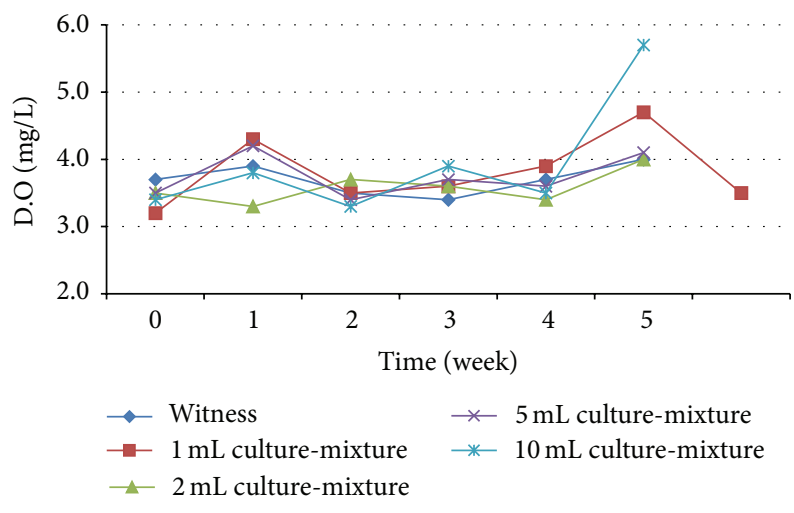

FIGURE 6: Dissolved oxygen results in the filtrate.

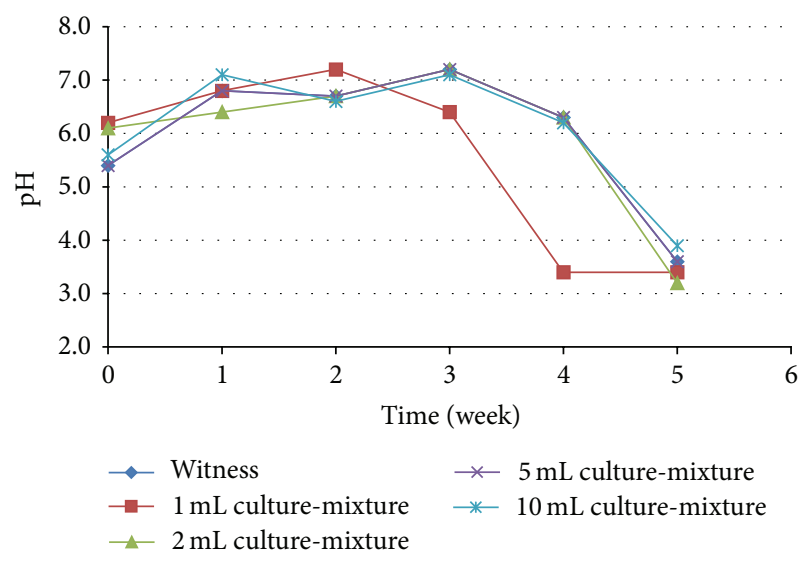

FIgURE 7: $\mathrm{pH}$ results in the filtrate.

performances also increased significantly. The TOC remediation performance increased most in the first week. In this parameter, the remediation performance was $28 \%, 30 \%, 73 \%$, and $83 \%$ in $1 \mathrm{~mL}, 2 \mathrm{~mL}, 5 \mathrm{~mL}$, and $10 \mathrm{~mL}$ mixed cultures, respectively. As Figure 2 shows, there was no significant change in the TOC remediation performance after the second week. As Figure 3 shows, the COD results are similar to the TOC results.

Figure 5 shows that, at the end of the fifth week, Aclonifen remediation results were $50 \%, 57 \%, 75 \%$, and $93 \%$ in $1 \mathrm{~mL}$, $2 \mathrm{~mL}, 5 \mathrm{~mL}$, and $10 \mathrm{~mL}$ mixed cultures, respectively. At the end of the fifth week, the remediation performance of the witness was $49 \%$, which is close to the remediation performance of the $1 \mathrm{~mL}$ mixed culture. The reason for such proximity is the fact that the microorganism population was not sufficient for bioremediation.

The dissolved oxygen results suggest a regular increase. This shows that the soil units were ventilated and microbial degradation occurred in aerobic conditions and it means that these soil microorganisms perform biodegradation abilities in aerobic conditions so most of microbial communities in soil are facultative anaerobe. (Figure 6).

The $\mathrm{pH}$ results suggest a gradual decrease over weeks which is why the soil filtrate had an acidic character. The bacterial and fungi activities produced carbon dioxide gas, which turned into carbonic acid upon the addition of water. The reaction between $\mathrm{CO}_{2}$ gas and water resulted in carbonic acid. This is evidence of the acidic nature of the environment (Figure 7).

In the study, high bioremediation rates were observed in soil experiments. Herbicides differ in chemical composition and react differently when incorporated into the soil system due to differences in chemical properties and interactions with soil components and environmental factors. Microbial community structure, often used as an indicator in monitoring soil quality, is affected by various environmental and growth factors, such as moisture, temperature, nutrient availability, and management practices. It was reported that the mineralization of some pesticides was mainly due to fungal activity. However, pesticides were not degraded when fungi or bacteria were separately inhibited [12].

Degradation of Aclonifen in soil under anaerobic conditions was investigated but it was not considered reliable to conclude high removal rate [33]. Aclonifen may be considered to be moderately-to-highly persistent in soil under aerobic conditions. Based on the findings from the screening test on ready biodegradability, water/sediment simulation test and soil Aclonifen appear to be susceptible to primary degradation (degradation of $>70 \%$ within 28 days) and not ultimate mineralization [34].

How long the pesticide remains in the soil depends on how strongly it is bound by soil components. It also depends on the environmental conditions such as soil water content at the time of application [35]. It can be said that some factors play a role in high bioremediation rates in the results. Soil fragments may contribute to pesticide adsorption and degradation, helping in the disappearance of these chemicals from the environment $[36,37]$. For example, calcareous marl soils show a good adsorption capacity with respect to the fine earth fraction [36]. It is also found that the soil fragments manifest a cation exchange capacity helping in removal of pesticides [38]. Acidity of the environment is another factor. Herbicide behavior in soils greatly depends on adsorption-desorption phenomena related to a wide array of soils with weakly acidic or weakly basic and neutral pesticides [37]. Adsorption to soil particles is also related to soil/water partition coefficient of the pesticides. The removal of pesticides generally increases with increasing value of this coefficient [39].

Bioremediation was high in the experiments; however, Vieno and Toivikko [40] studied some micropollutants, including Aclonifen, in a conventional biological and tertiary wastewater treatment plant and found that some environmentally harmful molecules (including Aclonifen) are still present at problematic levels after treatment. Results of our experiments show the importance of fungus-bacteria mixed cultures. Hai et al. [12] found that physical adsorption or uptake by the biomass without biochemical degradation of the pesticides appears to be a major removal mechanism by the fungus-only cultures. However, for the fungus-bacteria mixed cultures, biochemical degradation and physical adsorption/uptake both appear to have played roles in removing pesticides from the liquid phase. The pesticide removal rate by the fungi-bacteria culture was high compared to the previous bacterial culture studies under similar 
conditions. The results of the studies suggest that the presence of bacteria has a clear effect on the fungus morphology and nutrient depletion. However, it can be said that further researches are necessary to establish how bacteria affect fungus morphology and fungal activity by enzyme studies.

\section{Conclusion}

In previous aerobic laboratory soil degradation studies, the overall geometric mean half-life time DT50 value of Aclonifen at $20^{\circ} \mathrm{C}$ was found as 62.3 days [33]. In the same report degradation of Aclonifen in soil under anaerobic conditions was reviewed in one study but it was not considered reliable. Aclonifen may be considered to be moderately-tohighly persistent (DT50 $=32.2-134 \mathrm{~d}$ ) in soil, under aerobic conditions, at $20^{\circ} \mathrm{C}$ [33]. Based on the findings from the screening test on ready biodegradability, water/sediment simulation test and soil Aclonifen appear to be susceptible to primary degradation (degradation of $>70 \%$ within 28 days) and not ultimate mineralization [34].

In literature, there is no study about biodegradation or bioremediation of Aclonifen or diphenyl ether herbicides in liquid or soil media.

In the present study, five different units were prepared with the soil samples taken from the Thrace Region and $1900 \mu \mathrm{g} / \mathrm{L}$ Aclonifen was added to each of them.

According to the results of the study, the highest bioremediation was observed in the soil sample to which $10 \mathrm{~mL}$ of mixed culture of microorganisms was added and Aclonifen, $\mathrm{COD}, \mathrm{BOD}$, and TOC remediation was observed as $93.2 \%$, $97.8 \%, 98.8 \%$, and $98.7 \%$, respectively. The witness sample, which did not include any mixed culture of microorganisms, displayed 49\% Aclonifen remediation at the end of the fifth week, which suggests that the adsorption mechanism and the half-life of the pesticide were a factor. Among the mixed cultures that were grafted in different concentrations, the highest remediation performance resulting from degradation of microorganisms was $93 \%$ in the soil ecosystem that was placed in the $10 \mathrm{~mL}$ (approximately $10^{9} \mathrm{CFU} / \mathrm{mL}$ ) mixed culture. In the same environment, the COD, BOD, and TOC remediation performances were approximately 98\%, 99\%, and $99 \%$, respectively, at the end of the fifth week.

As a conclusion, bioremediation was high in the experiments and the results suggest that combining fungus and bacteria for removing recalcitrant compounds such as pesticides is beneficial but the mechanisms of pesticide removal are not entirely clear. For further insight into the results, the kinetics of pesticide removal and its toxic effect on bioaugmented fungus-bacteria mixed cultures need to be studied.

\section{Conflict of Interests}

The authors declare that there is no conflict of interests regarding the publication of this paper.

\section{Acknowledgments}

This research was supported by Y1ld1z Technical University Scientific Research Projects Coordination Department (Project no. 2012-05-02 KAP07).

\section{References}

[1] D. A. Vaccari, P. F. Strom, and J. E. Alleman, Environmental Biology for Engineers and Scientists, John Wiley \& Sons, 2006.

[2] L. J. R. Foster, B. H. Kwan, and T. Vancov, "Microbial degradation of the organophosphate pesticide, Ethion," FEMS Microbiology Letters, vol. 240, no. 1, pp. 49-53, 2004.

[3] P. Siripong, B. Oraphin, T. Sanro, and P. Duanporn, "Screening of fungi from natural sources in Thailand for degradation of polychlorinated hydrocarbons," American-Eurasian Journal of Agricultural and Environmental Sciences, vol. 5, no. 4, pp. 466472, 2009.

[4] M. Kumar and L. Philip, "Bioremediation of endosulfan contaminated soil and water-optimization of operating conditions in laboratory scale reactors," Journal of Hazardous Materials, vol. 136, no. 2, pp. 354-364, 2006.

[5] C. S. M. Masutti, Fate of fipronil in soils under sugar cane cultivation from the northeast of Brazil: sorption and degradation [Ph.D. thesis], Department of Soil Science, University of Saskatchewan, Saskatoon, Canada, 2003.

[6] R. Khoury, A. Geahchan, C. M. Coste, J.-F. Cooper, and A. Bobe, "Retention and degradation of metribuzin in sandy loam and clay soils of Lebanon," Weed Research, vol. 43, no. 4, pp. 252259, 2003.

[7] H. Ghadiri, "Degradation of endosulfan in a clay soil from cotton farms of western Queensland," Journal of Environmental Management, vol. 62, no. 2, pp. 155-169, 2001.

[8] Ö. Kilinc, R. Grasset, and S. Reynaud, "The herbicide aclonifen: the complex theoretical bases of sunflower tolerance," Pesticide Biochemistry and Physiology, vol. 100, no. 2, pp. 193-198, 2011.

[9] C. Vischetti, C. Marucchini, L. Leita, P. Cantone, F. Danuso, and R. Giovanardi, "Behaviour of two sunflower herbicides (metobromuron, aclonifen) in soil," European Journal of Agronomy, vol. 16, no. 3, pp. 231-238, 2002.

[10] Ö. Kilinç, "Aclonifen: the Identikit of a widely used herbicide," African Journal of Agricultural Research, vol. 6, no. 10, pp. 24112419, 2011.

[11] Ö. Kilinc, S. Reynaud, L. Perez, M. Tissut, and P. Ravanel, "Physiological and biochemical modes of action of the diphenylether aclonifen," Pesticide Biochemistry and Physiology, vol. 93, no. 2, pp. 65-71, 2009.

[12] F. I. Hai, O. Modin, K. Yamamoto, K. Fukushi, F. Nakajima, and L. D. Nghiem, "Pesticide removal by a mixed culture of bacteria and white-rot fungi," Journal of the Taiwan Institute of Chemical Engineers, vol. 43, no. 3, pp. 459-462, 2012.

[13] L. A. Richards, Diagnosis and Improvement of Saline and Alkali Soils, USDA Agriculture Handbook No. 60, U.S. Department of Agriculture, Washington, DC, USA, 1954.

[14] A. Tüzüner, Toprak ve Su Analiz Laboratuvarları El Kitabı, T.C. Tarım Orman ve Köyişleri Bakanlığı, Köy Hizmetleri Genel Müdürlüğü, Ankara, Turkey, 1990.

[15] A. Walkley and I. A. Black, "An examination of the Degtjareff method for determining organic carbon in soils: effect of variations in digestion conditions and of inorganic soil constituents," Soil Science, vol. 63, pp. 251-263, 1934.

[16] J. M. Bremner, Methods of Soil Analysis. Part 2: Chemical and Microbiological Properties, Agronomy Series no. 9, American Society of Agronomy, Madison, Wis, USA, 1965.

[17] G. J. Bouyoucos, "Hydrometer method improved for making particle size analyses of soils," Agronomy Journal, vol. 54, no. 5, pp. 464-465, 1962. 
[18] B. Kacar and İ. Kovancı, "Bitki, Toprak ve Gübrelerde Kimyasal Fosfor Analizleri ve Değerlendirilmesi," Tech. Rep. 354, Ege Üniversitesi Ziraat Fakültesi Yayınları, İzmir, Türkiye, 1982.

[19] B. Kacar, Bitki ve Topră̆ın Kimyasal Analizleri: II. Bitki Analizleri, Uygulama Klavuzu: 155, Ankara Üniversitesi Ziraat Fakültesi Yayınları, Ankara, Turkey, 1972.

[20] J. Heyrman, N. A. Logan, M. Rodríguez-Díaz et al., "Study of mural painting isolates, leading to the transfer of 'Bacillus maroccanus' and 'Bacillus carotarum' to Bacillus simplex, emended description of Bacillus simplex, re-examination of the strains previously attributed to 'Bacillus macroides' and description of Bacillus muralis sp. nov," International Journal of Systematic and Evolutionary Microbiology, vol. 55, no. 1, pp. 119131, 2005.

[21] J. Li, G. Yang, M. Wu, Y. Zhao, and S. Zhou, "Bacillus huizhouensis sp. nov., isolated from a paddy field soil," Antonie van Leeuwenhoek, vol. 106, no. 2, pp. 357-363, 2014.

[22] A. E. Bahig, E. A. Aly, A. A. Khaled, and K. A. Amel, "Isolation, characterization and application of bacterial population from agricultural soil at Sohag Province, Egypt," Journal of Microbiology, vol. 4, no. 2, pp. 42-50, 2008.

[23] B. Chitra, P. Harshab, G. Sadhana, and R. Soni, "Isolation characteriazation of bacterial isolates from agricultural soil at durg district," Indian Journal of Scientific Research, vol. 4, no. 1, pp. 221-226, 2014.

[24] A. Y.Z. Khalifa and A. A. Mohammed, "Isolation and characterization of an endophytic bacterium, Bacillus megaterium BMN1, associated with root-nodules of Medicago sativa L. growing in Al-Ahsaa region, Saudi Arabia," Annals of Microbiology, vol. 65, no. 2, pp. 1017-1026, 2015.

[25] T. J. White, T. Bruns, S. Lee, and J. Taylor, "Amplification and direct sequencing of fungal ribosomal RNA genes for phylogenetics," in PCR Protocols: A Guide to Methods and Applications, pp. 315-322, Academic Press, New York, NY, USA, 1990.

[26] B. Avcioglu-Dundar, "Personal communications," 2014.

[27] D. E. L. Cooke, A. Drenth, J. M. Duncan, G. Wagels, and C. M. Brasier, "A molecular phylogeny of phytophthora and related oomycetes," Fungal Genetics and Biology, vol. 30, no. 1, pp. 17-32, 2000.

[28] L. Zelles, P. Adrian, Q. Y. Bai et al., "Microbial activity measured in soils stored under different temperature and humidity conditions," Soil Biology and Biochemistry, vol. 23, no. 10, pp. 955-962, 1991.

[29] R. S. Travers, P. A. W. Martin, and C. F. Reichelderfer, "Selective process for efficient isolation of soil Bacillus sp," Applied and Environmental Microbiology, vol. 53, pp. 1263-1266, 1987.

[30] R. Cruikshank, Medical Microbiology, Churchill Livingstone, London, UK, 11th edition, 1972.

[31] E. Beutler, T. Gelbart, and W. Kuhl, "Interference of heparin with the polymerase chain reaction," Biotechniques, vol. 9, no. 2, article 166, 1990.

[32] W. G. Weisburg, S. M. Barns, D. A. Pelletier, and D. J. Lane, "16S ribosomal DNA amplification for phylogenetic study," Journal of Bacteriology, vol. 173, no. 2, pp. 697-703, 1991.

[33] EFSA, "Conclusion on the peer review of aclonifen," European Food Safety Authority-EFSA Scientific Report 149, EFSA, 2008.

[34] N. E. Humburg, Herbicide Handbook of the Weed Science Society of America, Weed Science Society of America, Champaign, Ill, USA, 6th edition, 1989.
[35] M. Arias-Estévez, E. López-Periago, E. Martínez-Carballo, J. Simal-Gándara, J.-C. Mejuto, and L. García-Río, “The mobility and degradation of pesticides in soils and the pollution of groundwater resources," Agriculture, Ecosystems and Environment, vol. 123, no. 4, pp. 247-260, 2008.

[36] C. Vischetti, G. Corti, E. Monaci, S. Cocco, L. Coppola, and A. Agnelli, "Pesticide adsorption and degradation in fine earth and rock fragments of two soils of different origin," Geoderma, vol. 154, no. 3-4, pp. 348-352, 2010.

[37] A. Boivin, R. Cherrier, and M. Schiavon, "A comparison of five pesticides adsorption and desorption processes in thirteen contrasting field soils," Chemosphere, vol. 61, no. 5, pp. 668-676, 2005.

[38] R. D. Wauchope, S. Yeh, J. B. H. J. Linders et al., "Pesticide soil sorption parameters: theory, measurement, uses, limitations and reliability," Pest Management Science, vol. 58, no. 5, pp. 419445, 2002.

[39] J. Vymazal and T. Březinová, “The use of constructed wetlands for removal of pesticides from agricultural runoff and drainage: a review," Environment International, vol. 75, pp. 11-20, 2015.

[40] N. Vieno and S. Toivikko, "The occurrence of environmentally relevant hazardous substances in Finnish wastewater treatment plants," in Proceedings of the IWA World Water Conference and Exhibition, Lisbon, Portugal, September 2014. 

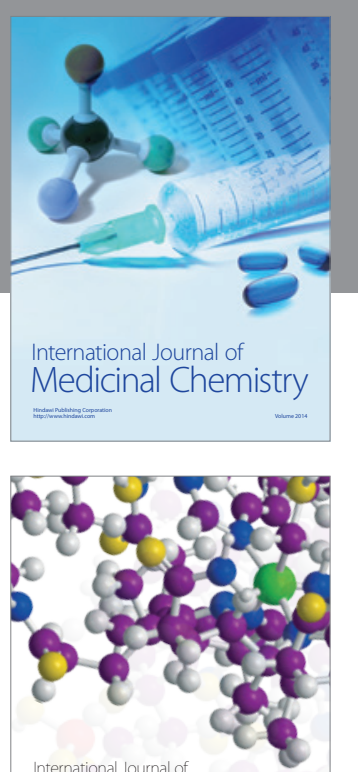

Carbohydrate Chemistry

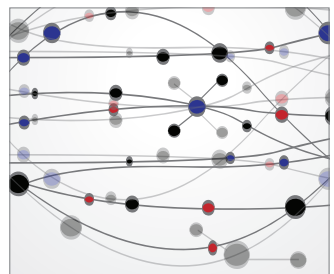

The Scientific World Journal
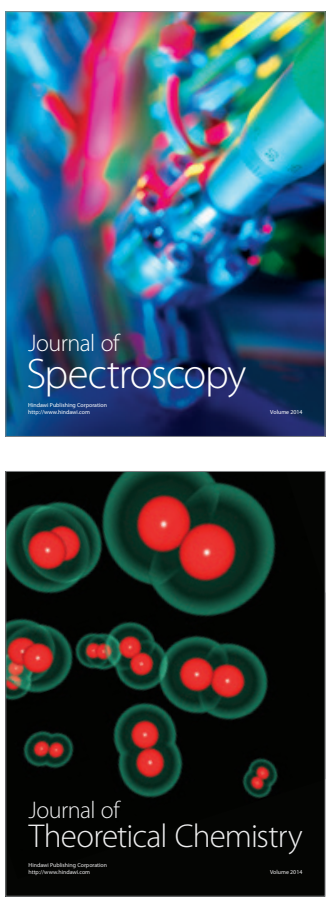
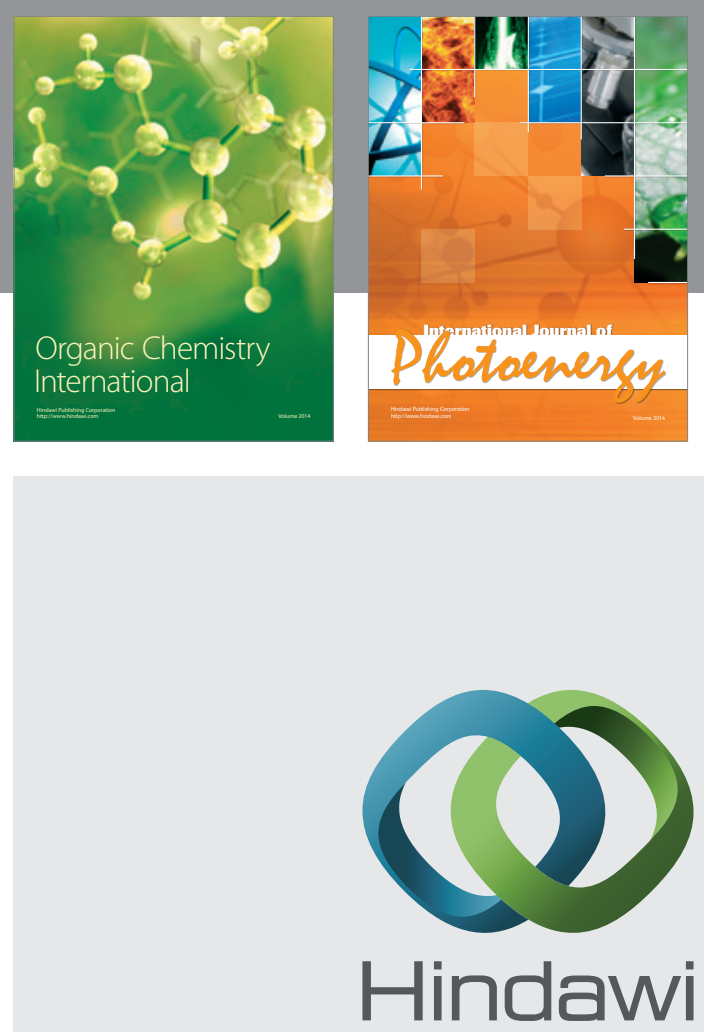

Submit your manuscripts at

http://www.hindawi.com

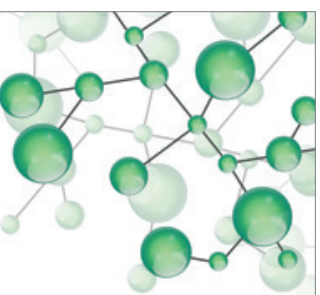

International Journal of

Inorganic Chemistry

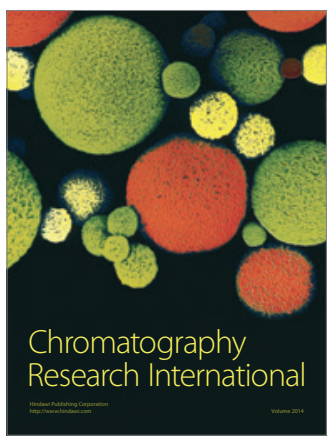

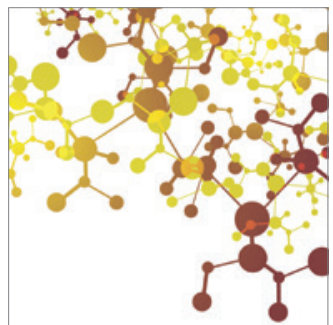

Applied Chemistry
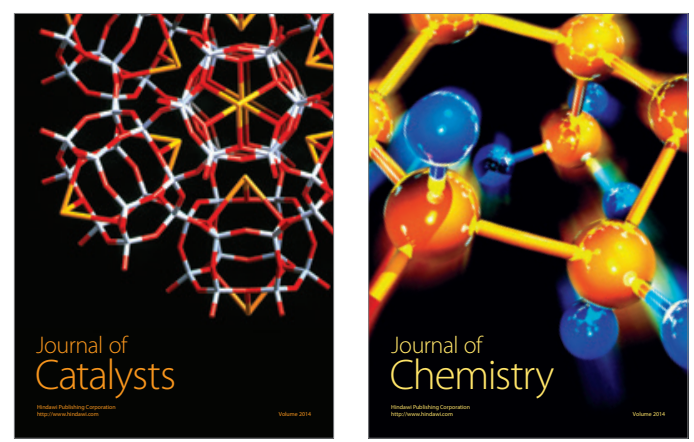
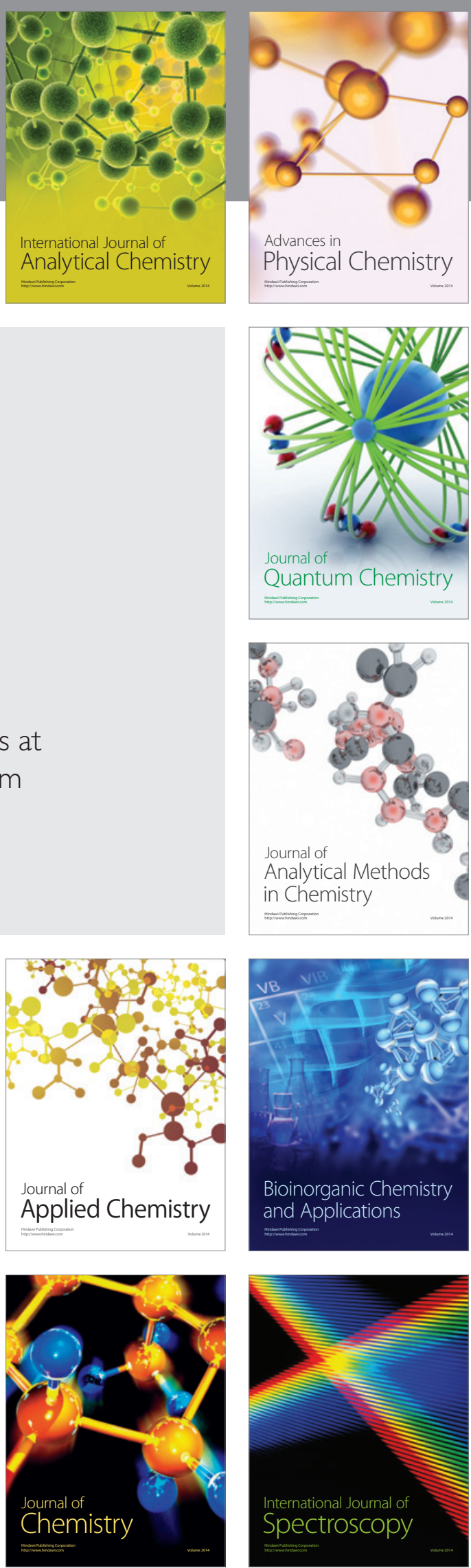